\title{
A comparative in vitro dissolution study of generic moxifloxacin immediate-release film coated tablets and referent pharmaceutical product
}

\author{
Emilija Janeva $^{1 *}$, Liljana Anastasova ${ }^{2}$, Irena Slaveska Spirevska ${ }^{1}$, Tatjana Rusevska ${ }^{1}$, \\ Tanja Bakovska Stoimenova ${ }^{1}$, Teuta Ibrahimi ${ }^{3}$, Rumenka Petkovska ${ }^{2}$ \\ ${ }^{1}$ Quality Control Department, Replek Farm Ltd., Kozle 188, 1000 Skopje, \\ Republic of North Macedonia \\ ${ }^{2}$ Institute of Applied Chemistry and Pharmaceutical Analysis, Faculty of Pharmacy, \\ Ss. Cyril and Methodius University, Mother Theresa 47, 1000 Skopje, \\ Republic of North Macedonia \\ ${ }^{3}$ Institute of Pharmaceutical Technology, Faculty of Pharmacy, \\ Ss. Cyril and Methodius University, Mother Theresa 47, 1000 Skopje, \\ Republic of North Macedonia
}

Received: January 2019; Accepted: February 2019

\begin{abstract}
Dissolution testing of generic immediate release solid dosage forms represents a valuable tool to obtain dissolution profiles and to establish the similarity/dissimilarity between tested dosage forms.

In this study, the in vitro dissolution profiles of generic immediate-release moxifloxacin (MOX) film coated tablets and a referent pharmaceutical product were compared and evaluated. The dissolution behavior of the generic product was investigated in three different dissolution media ( $\mathrm{pH}=1.2,4.5$ and 6.8). The amount of dissolved MOX was determined using validated UV spectrophotometric method. For comparison of the dissolution behavior, the similarity factor, $f_{2}$, was used.

The dissolution profile of the generic product showed a release of $>85 \%$ MOX in the time frame of 30 min, in all the tested dissolution media. The similarity factor, $f_{2}$, calculated from the comparison of the dissolution profiles of the generic and the referent pharmaceutical product in $\mathrm{pH}=1.2$ dissolution medium was 50,58 , thus the products were established as similar. Based on the results of our study, the dissolution similarity between the generic MOX immediate-release film coated tablet and the referent product could be successfully used as a part of the approach to ensure their in vivo bioequivalence.
\end{abstract}

Keywords: moxifloxacin, immediate-release solid dosage forms, dissolution, in vitro similarity

\section{Introduction}

The process of absorption and bioavailability of a drug from a solid pharmaceutical dosage form depends on two factors: the dissolution or solubilization of the drug under physiological conditions and the permeability across the gastrointestinal tract. Due to the critical nature of these steps, in vitro dissolution may be relevant for the prediction of the in vivo bioavailability of the drug (Cascone, 2017; Chow and Fanny, 1997; Pabla et al., 2009; Sayar et al., 2008; Shah, 2001).

\footnotetext{
* emilija40@ hotmail.com
} 
The in vitro dissolution test for immediate release dosage forms (tablets, capsules) is used in the evaluation of formulation development, batch quality control, in monitoring the manufacturing process and as a quality control test. Finally, it plays significant role in identifying the need for the bioequivalence (BE) studies related to Scale-Up and Post Approval Changes (SUPAC) and at the same time serves as a tool to identify unacceptable or substandard drug products (Anand et al., 2011; Fahmy and Abu-Gharbieh, 2014). Also, it can be used to support the bioavailability of a new drug product or the bioequivalence of an essentially similar product or variations (EMEA, 2001; FDA, 1997; Sayar et al., 2008).

Moxifloxacin [1-cyclopropyl-7[S,S]-2,8-diazabicyclo[4.3.0] non-8-yl-6-fluoro-8-methoxy-1,4-dihydro-4oxo-3-quinolone carboxylic acid hydrochloride] (MOX) (Fig. 1) is a fourth generation fluoroquinolone active against Gram-negative and some Gram-positive bacteria. MOX shows high intrinsic lipophylicity and good solubility at physiological pH. It is also rapidly absorbed following oral administration reaching the peak plasma concentration 2 hours after a $400 \mathrm{mg}$ dose (Moise et al., 2000). According to the Biopharmaceutical classification system (BCS), MOX can be considered as a highly soluble and highly permeable drug (class I compound) over the $\mathrm{pH}$ range of 1-7.5 at temperature of $37{ }^{\circ} \mathrm{C}$ (Saelim et al., 2015).

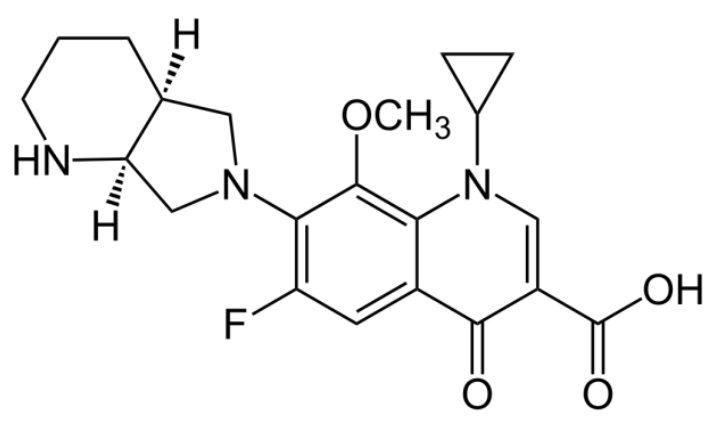

Fig. 1. Chemical structure of moxifloxacin.

Due to the clinical advantages of MOX there has been an increase in number in MOX generic products available on the market, such as film-coated tablets, ophthalmic solutions as well solutions for injection (Sultan, 2009). The use of different excipients in the preparation of generic products can result in a difference in their therapeutic response. The dissolution test is an economical and practical approach to identify bioavailability problems and assess the need for the in vivo bioavailability testing (Al Ameri et al., 2012).

The aim of the study was to compare the dissolution profile of a generic MOX immediate release film-coated tablet to the dissolution profile of referent pharmaceutical product and to investigate whether the tested product fulfills the requirements for similarity using in vitro dissolution testing.

\section{Material and methods}

\section{Reference substances, chemicals and reagents}

Moxifloxacin hydrochloride (MOX) working standard was provided by AUROBINDO Pharma Lilited, India (certificate number R0-CEP-2011-257). Methanol was supplied by Merck (Darmstadt, Germany) and potassium dihydrogen phosphate and hydrochloric acid were purchased from Sigma Aldrich (USA). Demineralized water was used throughout the entire analysis. All the chemicals used were of Ph. Eur grade. The tested immediate release film-coated tablets (generic product) were compared to a referent pharmaceutical product, both containing $400 \mathrm{mg} \mathrm{MOX}$.

\section{Comparative dissolution profile testing}

The comparative in vitro dissolution studies on the generic and the referent MOX product were conducted using USP apparatus II (the paddle method) at $50 \mathrm{rpm}$ and temperature of $37 \pm 0.5{ }^{\circ} \mathrm{C}$, with twelve replicates (SOTAX AT 7 Smart, Switzerland). Three different buffer solutions $(\mathrm{pH}=1.2,4.6,6.8)$ were used as dissolution media $(900$ $\mathrm{mL}$ ). $0.1 \mathrm{~mol} \mathrm{~L}^{-1} \mathrm{HCl}$ was used as the buffer $\mathrm{pH}=1.2$, whereas the buffers $\mathrm{pH}=4.5$ and $\mathrm{pH}=6.8$ consisted of 0.05 mol L-1 potassium dihydrogen phosphate according to the requirements of the guideline on the investigation of the bioequivalence (EMA, 2010).

In all experiments, at predetermined time intervals $(5,15,20,30,45$ and $60 \mathrm{~min})$, sample aliquots of $10 \mathrm{~mL}$ of dissolution medium were withdrawn and no fresh dissolution medium was added to the vessel. Prior UV analysis, dissolution test samples were subjected to filtration (Filter paper disks (Quant, 391-DIA grade)) and appropriate dilution.

\section{UV spectrophotometric determination of $M O X$}

The MOX concentration in the tested dissolution samples was quantified using UV-spectrophotometric method on a VARIAN Cary Win 50 Scan UV/Vis spectrophotometer, in a $1 \mathrm{~cm}$ cell at wavelength of $295 \pm 2 \mathrm{~nm}$ against a dissolution medium as a blank. MOX stock standard solution $\left(0.55 \mathrm{mg} \mathrm{mL}^{-1}\right)$, used for all dissolution tests, was prepared in methanol. This solution was further diluted with $0.1 \mathrm{~mol} \mathrm{~L}^{-1} \mathrm{HCl}$ to obtain working standard solution of MOX $\left(0.004 \mathrm{mg} \mathrm{mL}^{-1}\right)$. Prior to sample testing, the proposed method was validated in respect to selectivity, linearity and range, accuracy and precision (system repeatability, method repeatability and intermediate precision), according to the requirements proposed in ICH Guideline Q2A (ICH Q2A, 2005).

\section{Analysis of the in vitro dissolution data}

In order to compare the dissolution profiles of the tested and the reference product the similarity factor $\left(f_{2}\right)$ 
was calculated. The similarity factor $\left(f_{2}\right)$ is used to express the similarity between the amount of dissolved substance $(\%)$ between the tested and the reference product, using the following formula:

$$
f_{2}=50 \log \left\{\left[1+\frac{1}{n} \sum_{t}^{n}\left(R_{t}-T_{t}\right)^{2}\right]^{-0.5}\right\} * 100
$$

where $n$ is the number of time points, $R_{t}$ is the average percent (\%) of active ingredient dissolved from the reference product at the defined time points (average of 12 units), $\mathrm{T}_{\mathrm{t}}$ is the average percent (\%) of active ingredient dissolved from test product at a defined time points (average of 12 units). The value of the similarity product above 50 (50-100) confirms the similarity between the two dissolution profiles.

\section{Results and discussion}

\section{Method validation}

Method validation represents the process used to confirm that the analytical procedure used for a specific test is suitable for its intended use. In this study, the UV spectrophotometric method used for quantification of MOX in the dissolution samples was validated in respect to selectivity, linearity and range, precision and accuracy.

Selectivity - The selectivity represents the ability of the method to differentiate the analyte (s) of interest and other components in the sample matrix. The comparison of the spectral curves of the placebo solution, blank solution and the overlaid spectral curves of standard solution of MOX and dissolution test sample (Fig. 2) revealed no interference from other substances present in the placebo or the blank solution. Thus, the UV spectrophotometric method was selective for quantification of MOX concentration in samples obtained from the dissolution media.

Linearity - The linearity of the method was determined in the range of $2-5 \mu \mathrm{g} \mathrm{mL}^{-1}$ which is $50-125$ $\%$ of the working concentration. Each measurement was performed in triplicate, and the results were evaluated by linear regression analysis using the least squares regression method. The method showed to be linear in the concentration range studied with a correlation coefficient of 0.9998 (minimal acceptable value is $\mathrm{R}^{2} \geq 0.99$ ). The regression equation obtained was $\mathrm{y}=0.1143 \mathrm{x}-0.0038$.

Precision - The precision of the UV spectrophotometric method was evaluated through repeatability (system and method repetability) and intermediate precision. The repeatability of the system acomplished through six determinations of the absorbance of standard solutions containing $\operatorname{MOX}\left(0.004 \mathrm{mg} \mathrm{mL}^{-1}\right)$ demonstrated that the maximum value for the RSD is $0.082 \%$. The method precision was evaluated by determination of the percent $(\%)$ of dissolved MOX through six samplings from each of the six vessels of the apparatus. The results are presented in Table 1.

As it can be seen from Table 1, the RSD (\%) from all of the determinations are within the accepted limits of not more than $2 \%$, indicating that the analytical procedure is precise for determination of moxifloxacin.

The results from the determination of the intermediate precision are shown in Table 2. The intermediate precision assessed on two consecutive days, by two different analysts showed that the RSD value of the entire determination is not more than $3 \%$ for all the tested sets of tablets, thus the method is precise.

Accuracy - Accuracy of the method was evaluated through the study of analytical recovery. The results are shown in Table 3. The percentages of the obtained recoveries are in the range 95.0-105.0\%, indicating good accuracy of the method.

\section{The in vitro dissolution studies}

The in vitro dissolution studies can sometimes be used as an alternative to the in vivo studies in assessing the bioequivalence of immediate-release solid dosage forms containing BSC class I drugs, such as MOX for

Table 1. Results obtained for the testing of method precision

\begin{tabular}{ccccccc}
\hline \hline & Vessel 1 & Vessel 2 & Vessel 3 & Vessel 4 & Vessel 5 & Vessel 6 \\
\hline 1. & 91.45 & 93.85 & 91.25 & 94.52 & 90.78 & $93.33^{*}$ \\
2. & 92.08 & 92.91 & 92.13 & 93.13 & 90.82 & 94.16 \\
3. & 91.36 & 93.16 & 91.42 & 94.22 & 91.13 & 93.75 \\
4. & 92.15 & 93.04 & 92.61 & 94.91 & 91.05 & 93.28 \\
5. & 92.94 & 93.22 & 91.66 & 93.57 & 90.66 & 92.46 \\
6. & 92.47 & 93.37 & 92.58 & 94.21 & 92.08 & 93.14 \\
average & 92.01 & 93.26 & 91.95 & 94.01 & 91.01 & 93.35 \\
SD & 0.60 & 0.33 & 0.59 & 0.65 & 0.52 & 0.58 \\
RSD $(\%)$ & 0.65 & 0.35 & 0.64 & 0.69 & 0.57 & 0.62 \\
\hline
\end{tabular}

*Results are expressed as cumulative \% of dissolved MOX after $45 \mathrm{~min}$ in $0.1 \mathrm{~mol} \mathrm{~L}^{-1} \mathrm{HCl}$ 
Table 2. Intermediate precision results of the UV spectrophotometric method

\begin{tabular}{cccc}
\hline Day & $\begin{array}{c}\text { Analyst A } \\
(\mathrm{n}=6) \% \text { dissolved }\end{array}$ & $\begin{array}{c}\text { Analyst B } \\
(\mathrm{n}=6) \% \text { dissolved }\end{array}$ & $\begin{array}{c}\text { Analyst C } \\
(\mathrm{n}=6) \% \text { dissolved* }\end{array}$ \\
\hline 1 & 91.33 & 92.65 & 93.04 \\
2 & 90.74 & 90.06 & 91.33 \\
$\begin{array}{c}\text { Difference between analysts } \\
(\%)\end{array}$ & 0.59 & 2.59 & 1.71 \\
\hline
\end{tabular}

*Cummulative percent of dissolved MOX after $45 \mathrm{~min}$ in $0.1 \mathrm{~mol} \mathrm{~L}^{-1} \mathrm{HCl}$
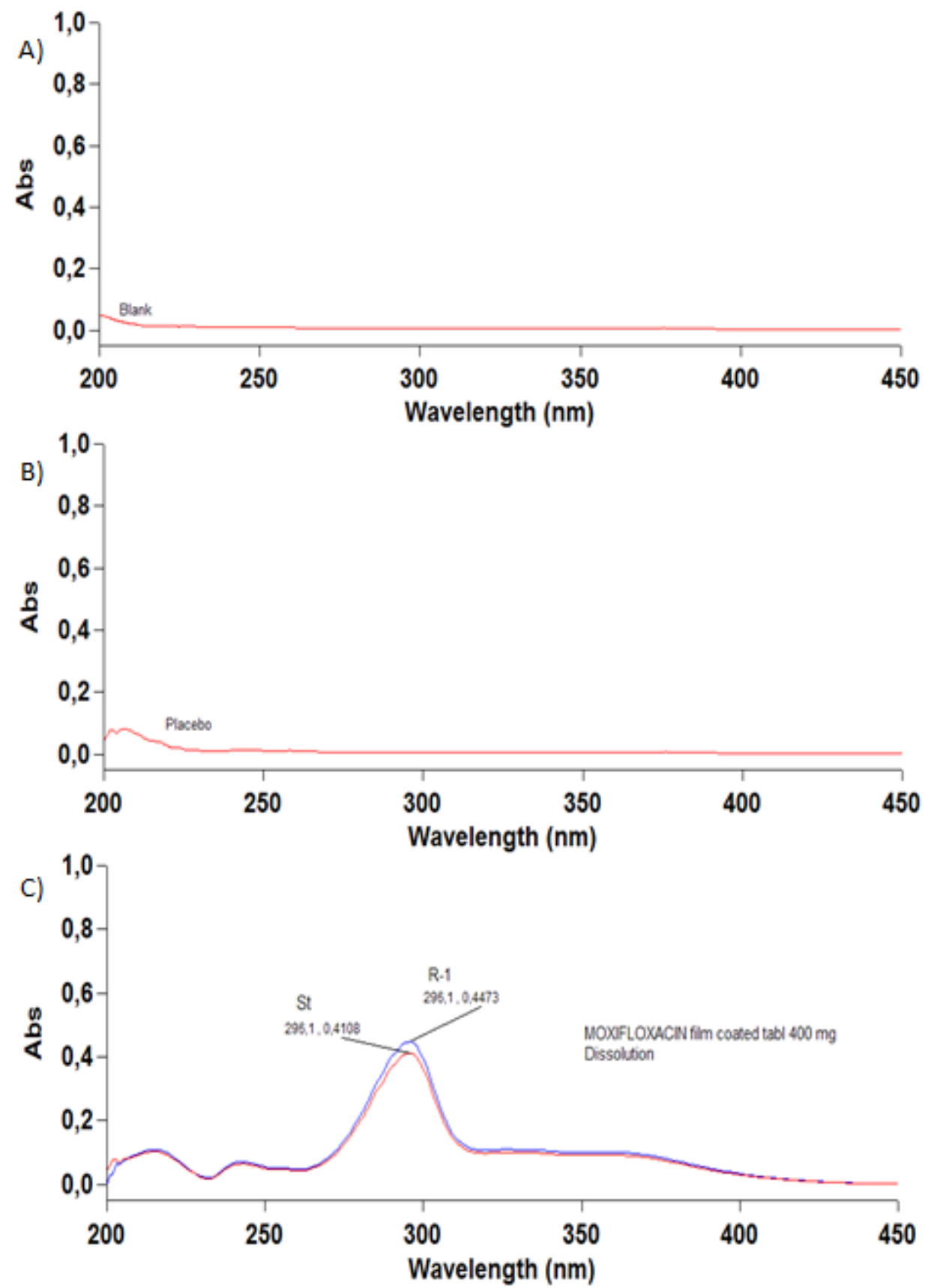

Fig. 2. Representative spectral curves of: A) placebo solution, B) blank solution and C) overlaid spectral curves of standard solution and dissolution test sample containing MOX. 
Table 3. Result from the testing of the accuracy of the method

\begin{tabular}{cccc}
\hline $\begin{array}{c}\text { Working concentration } \\
(\%)\end{array}$ & $\begin{array}{c}\text { Added } \\
(\mu \mathrm{g} / \mathrm{mL})\end{array}$ & $\begin{array}{c}\text { Determined } \\
(\mu \mathrm{g} / \mathrm{mL})\end{array}$ & $\begin{array}{c}\text { Accuracy* } \\
(\%) \pm \mathrm{SD}\end{array}$ \\
\hline 80 & 2.03 & 2.05 & $100.99 \pm 0.49$ \\
100 & 3.98 & 3.99 & $100.17 \pm 0.81$ \\
120 & 5.11 & 5.17 & $101.17 \pm 0.71$ \\
\hline *expressed as average recovery from three determinations $(\mathrm{n}=3)$ &
\end{tabular}
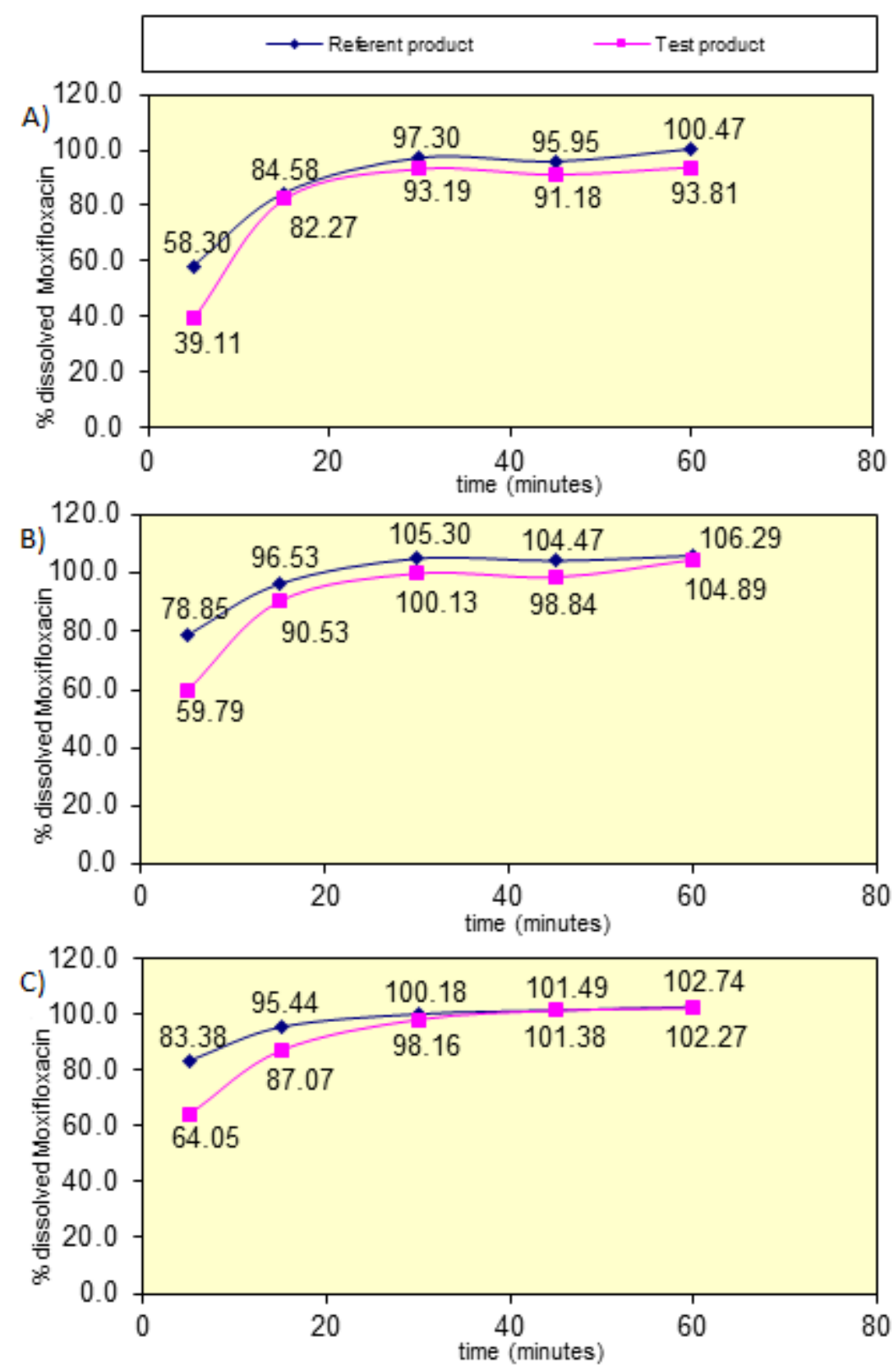

Fig. 3. Comparative graphical representation of the release profiles of generic MOX film coated tablets and the reference product in three different media: A) $\mathrm{pH}=1.2 \mathrm{~B}$ ) $\mathrm{pH}=4.5 \mathrm{C}$ ) $\mathrm{pH}=6.8$. 
Table 4. Comparative dissolution profiles on reference pharmaceutical MOX film coated tablets (R) and generic film coated MOX tablets $(\mathrm{G})$ in different dissolution media $(\mathrm{pH}=1.2 ; 4.5 ; 6.8)$

\begin{tabular}{lcccccc}
\hline $\begin{array}{l}\text { Time } \\
(\mathrm{min})\end{array}$ & \multicolumn{2}{c}{$\mathrm{pH}=1.2$} & \multicolumn{2}{c}{ Dissolution media } \\
\hline & $\mathrm{R}$ & $\mathrm{G}$ & $\mathrm{R}$ & $\mathrm{G}$ & $\mathrm{R}$ & $\mathrm{k}=4.5$ \\
\hline 5 & $58.30 \pm 10.64$ & $39.11 \pm 7.29$ & $78.85 \pm 8.43$ & $59.79 \pm 8.06$ & $83.38 \pm 9.37$ & $64.05 \pm 7.74 *$ \\
15 & $84.58 \pm 5.88$ & $82.27 \pm 4.33$ & $96.53 \pm 1.79$ & $90.53 \pm 9.72$ & $95.44 \pm 2.62$ & $87.07 \pm 5.93$ \\
30 & $97.30 \pm 2.09$ & $93.19 \pm 4.34$ & $105.30 \pm 1.02$ & $100.13 \pm 4.88$ & $100.18 \pm 0.95$ & $98.16 \pm 3.63$ \\
45 & $95.95 \pm 4.34$ & $91.18 \pm 3.85$ & $104.47 \pm 2.90$ & $98.84 \pm 5.22$ & $101.49 \pm 1.34$ & $101.38 \pm 3.68$ \\
60 & $100.47 \pm 1.91$ & $93.81 \pm 4.51$ & $106.29 \pm 1.69$ & $104.89 \pm 3.10$ & $102.74 \pm 2.01$ & $102.27 \pm 2.89$ \\
\hline$f_{2}$ & 50.85 & \multicolumn{3}{c}{$/$} \\
\hline
\end{tabular}

*Results are expressed as average percent (\%) of dissolved MOX from 12 analyzed samples \pm RSD

both cost reduction and ethical considerations (Polli, 2008). Not all generic products containing the same drug in similar dosage forms and strengths are equivalent. Class I drugs according to the BCS with rapid dissolution may contain the same active ingredient and amount ingredient but may show significant differences to in vitro equivalence requirements (Villarroel et al., 2014). The comparative in vitro dissolution study should ensure the similarity between the reference and tested product in three different media considered relevant for the absorption in the gastrointestinal system (EMA, 2010; Helmy et al., 2016; Varillas et al., 2018).

The results obtained from the comparative in vitro dissolution study are summarized in Table 4 and the corresponding dissolution profiles of the tested generic vs the reference product are presented graphically in Fig. 3 .

As it can be seen from the results presented in Table 4 , both tested products showed a release $>85 \%$ in $30 \mathrm{~min}$, in all three tested media. Due to the rapid dissolution of the active substance, the similarity factor, $f_{2}$ was calculated only for the medium with $\mathrm{pH}=1.2$ and its value was 50.85 which fall within the range of acceptance criteria. The dissolution profiles in phosphate buffer $\mathrm{pH}=4.5$ and phosphate buffer $\mathrm{pH}=6.8$ may be accepted as similar without further mathematical evaluation (EMA, 2010).

The generic MOX immediate-release film coated tablet and the referent pharmaceutical product could be considered as in vitro equivalents.

\section{Conclusion}

The in vitro dissolution similarity of a generic MOX immediate-release film coated tablet and a reference pharmaceutical product was assessed, using validated UV spectrophotometric method. The validation results indicated that applied method was selective, linear, precise and accurate. The tested tablet released MOX satisfactorily, with more than $85 \%$ dissolved in the first 30 minutes and showed similar in vitro dissolution behavior with the reference product. The estimation of the in vitro dissolution similarity could be used as an important segment of the approach to ensure the in vivo bioequivalence and the therapeutic equivalence, especially in the case of BSC Class I drugs such as MOX.

\section{References}

Al Ameri, N.M., Nayuni, N., Anil Kumar, K.G., Perrett, D., Tucker, A., Johnston, A., 2012. The differences between branded and generic medicines using solid dosage forms: In vitro dissolution testing. Res. Phar. Sci. 2, 1-8. Available at: https://doi.org/10.1016/j.rinphs.2011.12.001.

Anand, O., Lawrence, Y., Conner, D., Davit, B., 2011. Dissolution testing for generic drugs: an FDA perspective. The AAPS J. 13, 328-335. Available at: https://doi.org/10.1208/s12248-011-9272-y.

Cascone, S., 2017. Modeling and comparison of release profiles: effect of the dissolution method. Eur. J. Pharm. Sci. 106, 352-361. Available at: https://doi.org/10.1016/j.ejps.2017.06.021.

Chow, S., Fanny, Y.K., 1997. Statistical comparison between dissolution profiles of drug products. J. Biopharm. Stat. 7, 241-258. Available at: https://doi.org/10.1080/10543409708835184.

Fahmy, S., Abu-Gharbieh, E., 2014. In vitro dissolution and in vivo bioavailability of six brands of ciprofloxacin tablets administered in rabbits and their pharmacokinetic modeling. BioMed Res. Int., article ID 590848, 8 pages. Available at: https://doi.org/10.1155/2014/590848.

FDA. The Biopharmaceutical Classification System (BCS) Guidance Office of Pharmaceutical Science. CDER 2006. 
Guideline on the investigation of Bioequivalence; CPMP/EWP/QWP/1401/98 Rev. 1; Committee for medicinal products for human use (CHMP), European Medicines Agency: London, 2010. Available at: https://www.ema.europa.eu/en/documents/scientificguideline/guideline-investigation-bioequivalencerev1_en.pdf .

Helmy, S., Bedaiwy, H., 2016. In vitro dissolution similarity as a surrogate for in vivo bioavailability and therapeutic equivalence. Diss. Tech. 32-39. Available at: https://doi.org/10.14227/DT230316P32.

International Conference on harmonization of technical requirements for registration of pharmaceuticals for human use. ICH Harmonized Tripartite Guideline: Validation of analytical procedures: Text and Methodology Q2(R1). ICH, 2005. Available at:

https://www.ema.europa.eu/en/documents/scientificguideline/ich-q-2-r1-validation-analytical-procedures-textmethodology-step-5_en.pdf.

Moise, P.A., Birmingam, M.C., Schentag, J.J., 2000. Pharmacokinetics and metabolism of moxifloxacin. Drugs Today (Barc) 36, 229-244. Available at: https://doi.org/10.1358/dot.2000.36.4.570201.

Pabla, D., Akhlaghi, F., Zia, H., 2009. A comparative pH-profile dissolution study of selected commercial levothyroxine products using inductively coupled plasma mass spectrometry. Int. J. Pharm. Biopharm. 72, 105-110. Available at: https://doi.org/10.1016/j.ejpb.2008.10.008.

Polli, J.E., 2008. In vitro studies are sometimes better than conventional pharmacokinetic in vivo studies in asessin bioequivalence of immediate-release solid oral dosage forms. AAPS J. 10, 263-271. Available at: https://doi.org/10.1208/s12248-008-9027-6.

Saelim, N., Suksawaeng, K., Chupan, J., Techatanawat, I., 2016. Biopharmaceutics classification system (BCS)-based biowaiver for immediate release solid oral dosage forms of moxifloxacin hydrochloride (moxiflox GPO) manufactured by the government pharmaceutical organization (GPO). Asian J. Pharm. Sci. II, 235-236. Available at: https://doi.org/10.1016/j.ajps.2015.11.016.

Sayar, E., Sahin, S., Cevhroglu, S., Hincal, A., 2008. Comparison of the dissolution profiles of two commercially available Co-trimoxazole tablets. Fabad J. Pharm. Sci. 33, 87-94.

Shah, V., 2001. Dissolution: a quality control test vs bioequivalent test. Diss. tech. 8, 1-2. Available at: https://doi.org//10.14227/DT080401P6.

Sultan, M., 2009. New, simple and validated kinetic spectrophotometric method for determination of moxifloxacin in its pharmaceutical formulations. Arab. J. Chem. 2, 79-85. Available at: https://doi.org/10.1016/j.arabjc.2009.10.002.

Varillas, M., Brevedan, M., Gonzales Vidal, N., 2018. Pharmaceutical equivalence and similarity studies of metoclopramide tablets. Diss. Tech. 14-21. Available at: https://doi.org/10.14227/DT250118P14.

Villarroel, S.A., Zuo, J., Lobenberg, R., 2014. Investigating the dissolution profiles of amoxicillin, metronidazole and zidovudine formulations used in Trinidad and Tobago, West Indias. AAPS PharmSci. Tech. 15, 1060-1069. Available at: https://doi.org/10.1208/s12249-014-0132-9.

Компаративна in vitro студија на растворливост на генерички брзо-ослободувачки филм-обложени таблети со моксифлоксацин и референтен фармацевтски производ

\section{Емилија Јанева $^{1 *}$, Лилјана Анастасова ${ }^{2}$, Ирена Славеска Спиревска ${ }^{1}$, Татјана Русевска ${ }^{1}$, Тања Баковска Стоименова ${ }^{1}$, Теута Ибрахими ${ }^{3}$, Руменка Петковска ${ }^{2}$}

${ }^{1}$ Сектор за контрола на квалитет, Реплек Фарм, Козле 188, 1000 Скопје, Република Северна Македонија

${ }^{2}$ Институт за применета хемија и фармацевтски анализи, Фармацевтски факултет,

Универзитет „Св. Кирил и Методиј“, Мајка Тереза 47, 1000 Скопје,

Република Северна Македонија

${ }^{2}$ Институт за фармацевтска технологија, Фармацевтски факултет,

Универзитет „Св. Кирил и Методиј“, Мајка Тереза 47, 1000 Скопје,

Република Северна Македонија

Клучни зборови: моксифлоксацин, дозирани форми со брзо ослободување, ратворливост, in vitro сличност 
Тестот на растворливост за генерички брзо-ослободувачки цврсти дозирани форми претставува значајна алатка за добивање на профилот на растворливост на активната компонента, како и за утврдување на сличноста/разликите меѓу испитувани дозирани форми.

Во ова истражување се споредени и проценети in vitro профилите на растворливост на генерички брзоослободувачки филм обложени таблети со моксифлоксацин (MOX) и референтен фармацевтски производ. Растворливоста беше испитана во три различни дисолуциски медиуми ( $\mathrm{pH}=1,2 ; 4,5$ и 6,8). Содржината на ослободен MOX беше одредена со примена на валидиран UV спектрофотометриски метод. Профилите на растворливост беа споредени преку факторот на сличност, $f_{2}$.

Профилот на растворливост на испитуваните генерички филм обложени таблети покажа дека $>85 \%$ од активната компонента MOX се ослободува за време од $30 \mathrm{~min}$, во сите три дисолуциски медиуми. Факторот на сличност, $f_{2}$, добиен преку споредба со профилот на растворливост на референтниот производ во медиум со $\mathrm{pH}=1,2$ изнесуваше 50,58 со што беше утврдено дека испитуваните таблети се слични. Сличноста во профилите на растворливост на MOX филм обложените таблети претставува значаен сегмент во пристапот за обезбедување на in vivo биоеквиваленција на испитуваните производи. 